\title{
Community structure and activity of sulfate-reducing bacteria in an intertidal surface sediment: a multi-method approach
}

\author{
Enrique Llobet-Brossa, Ralf Rabus*, Michael E. Böttcher, Martin Könneke, \\ Niko Finke, Andreas Schramm**, Rikke L. Meyer ${ }^{* * *}$, Stefan Grötzschel, \\ Ramon Rosselló-Mora ${ }^{* * *}$, Rudolf Amann
}

Max Planck Institute for Marine Microbiology, Celsiusstr. 1, 28359 Bremen, Germany

\begin{abstract}
The community structure of sulfate-reducing bacteria (SRB) in an intertidal mud flat of the German Wadden Sea (Site Dangast, Jade Bay) was studied and related to sedimentary biogeochemical gradients and processes. Below the penetration depths of oxygen $(\sim 3 \mathrm{~mm})$ and nitrate $(\sim 4 \mathrm{~mm})$, the presence of dissolved iron and manganese and the absence of dissolved sulfide indicated suboxic conditions within the top $10 \mathrm{~cm}$ of the sediment. Moderate to high bacterial sulfate reduction rates were measured with radiotracers throughout the sediment, and dissimilatory sulfate reduction was also demonstrated by the presence of acid-volatile sulfides (AVS, essentially iron monosulfide). Stable sulfur isotope discrimination between dissolved sulfate and AVS was dominated by sulfate reduction. The diversity of SRB was studied using denaturant gradient gel electrophoresis of 16S rDNA, phospholipid fatty acid analysis and counting viable cells with the most probable number technique. Phylogenetic groups of SRB identified with these techniques were almost evenly distributed throughout the top $20 \mathrm{~cm}$ of the sediment. Application of fluorescence in situ hybridization, however, demonstrated a maximum of active members of the Desulfovibrio and Desulfosarcina-Desulfococcus-Desulfofrigus groups between 2 and $3 \mathrm{~cm}$ depth. These 2 groups encompass acetate and lactate utilizing $\mathrm{SRB}$. The coincidence of this SRB maximum with a local maximum of sulfate reduction rates and the depletion of acetate and lactate reflects the microbiological processes related to sulfate reduction.
\end{abstract}

KEY WORDS: Sulfate-reducing bacteria $\cdot$ Microbial diversity $\cdot$ Intertidal sediments $\cdot$ Sulfate reduction rates $\cdot$ Stable sulfur isotopes $\cdot$ Phospholipid fatty acids $\cdot$ Most probable number $\cdot$ Fluorescence in situ hybridization Resale or republication not permitted without written consent of the publisher

\section{INTRODUCTION}

Continental margin sediments include shelf sediments and intertidal mud flats of the coastal ranges.

\footnotetext{
*Corresponding author. E-mail: rrabus@mpi-bremen.de Present addresses:

${ }^{* *}$ Lehrstuhl für ökologische Mikrobiologie, BITÖK, Universität Bayreuth, Dr. Hans-Frisch-Str. 1-3, 95440 Bayreuth, Germany

***Aarhus University, Institute for Biological Sciences, Dept. for Microbial Ecology, Ny Munkegade, Bygn 540, 8000 Aarhus C, Denmark

****Area de Microbiologia, Departament de Recursos Naturals, IMEDEA (CSIC-UIB), Crtra. Valldemossa Km 7.5, 07071 Palma de Mallorca, Spain
}

These sediments are generally characterized by a high input of organic matter. Up to $30 \%$ of the oceanic primary production takes place in the shelf areas. From this, 25 to $50 \%$ sinks to the sediment (Wollast 1991). In addition, the deltaic areas of the shelf regions are receiving up to $90 \%$ of the global flux of particles and organic matter transported by rivers to the oceans (Gibbs 1981). Since most of the deposited matter is remineralized (Berner 1982), continental margin sediments play a prominent role in the marine carbon cycle, even though they encompass only $10 \%$ of the total ocean area. The oxidation of organic carbon is performed by microorganisms that employ an array of electron acceptors, each allowing a different yield of free energy. In accordance with the decreasing yields, 
a zonation of the oxidants is usually observed in the vertical sediment profiles: $\mathrm{O}_{2}, \mathrm{NO}_{3}{ }^{-}, \mathrm{Fe}(\mathrm{III})$ and $\mathrm{Mn}(\mathrm{IV}), \mathrm{SO}_{4}{ }^{2-}$, and finally $\mathrm{CO}_{2}$ (Froelich et al. 1979). Using the ${ }^{35} \mathrm{SO}_{4}{ }^{2-}$ radiotracer technique (Jørgensen 1978, King 2001) it was shown that up to about $50 \%$ of the organic matter in continental margin sediments is mineralized via microbial sulfate reduction (Jørgensen 1982a). Since sulfate concentration in seawater is about $28 \mathrm{mM}$, it may still be abundant in deeper layers of marine sediments and, consequently, the dominant electron acceptor (Fenchel et al. 1998). The areal rates of dissimilatory sulfate reduction in intertidal sediments may vary considerably between about 0.2 and $104 \mathrm{mmol} \mathrm{m}^{-2} \mathrm{~d}^{-1}$ (Trudinger 1992). Sulfate reduction rates are controlled by temperature (Vosjan 1974) and the availability of reactive organic compounds (Schubert et al. 2000), and are correlated to the abundance of sulfate-reducing bacteria (SRB) (Sahm et al. 1999, Böttcher et al. 2000).

The importance of sulfate reduction for the remineralization of organic carbon in marine sediments is reflected also by the variety of metabolic capacities of SRB isolated from these environments. Pure cultures of SRB have been shown to utilize $\mathrm{H}_{2}$ and organic substrates such as short chain fatty acids, alcohols and aromatic compounds, and to completely oxidize acetate to $\mathrm{CO}_{2}$ (Widdel 1988, Rabus et al. 2000), all important substrates in the anoxic zones of marine sediments. Phylogenetic analysis of isolates (Devereux et al. 1990) and the introduction of 16S rRNA based molecular tools (Amann et al. 1995) now allow SRB to be identified and quantified in their natural habitat. This type of investigation was only recently applied to marine sediments (Devereux et al. 1996, Llobet-Brossa et al. 1998, Ravenschlag et al. 1999, 2000, Sahm et al. 1999, Bowman et al. 2000, Wieringa et al. 2000).
Up to now, the contribution of SRB to the remineralization of carbon in marine sediments has mainly been studied by application of selected, specialized methods. However, the complexity of the system requires multiple methods in order to obtain a comprehensive overview of the controlling factors and their interactions. Therefore, we applied a fully integrated approach by combining cultivation-dependent and -independent microbiological techniques with biogeochemical and stable isotope analyses, to advance our understanding of the relationship between the community structure of sulfate-reducers and zones of dominant usage of the different electron acceptors. For the present study, a marine sediment with high activity of SRB was chosen. Site Dangast, an intertidal sediment at the southern boundary of the North Sea, met these criteria due to high loads of organic material and abundant sulfate.

\section{MATERIALS AND METHODS}

Study site. The sampling station is located in the 'Jadebusen' (Jade Bay), a meso- to macrotidal embayment (Irion 1994), which is situated in the coastal area to the west of the Weser estuary in the northern part of Lower Saxony (Germany). The sediment is exposed to the air for about $5 \mathrm{~h}$, leaving it inundated for about $7 \mathrm{~h}$. The sampling station, Site Dangast, is located $2 \mathrm{~km}$ west of the small village of Dangast, about $25 \mathrm{~m}$ west of a tidal creek ('Dangast Tief'), connected to a freshwater outlet ('Dangast Siel') and about $15 \mathrm{~m}$ north from the shore-line (Fig. 1).

Processing of sediment samples. Sediment cores were obtained on June 28, 1999, at low tide with polycarbonate tubes (diameter 8 to $10 \mathrm{~cm}$; length $50 \mathrm{~cm}$ ).

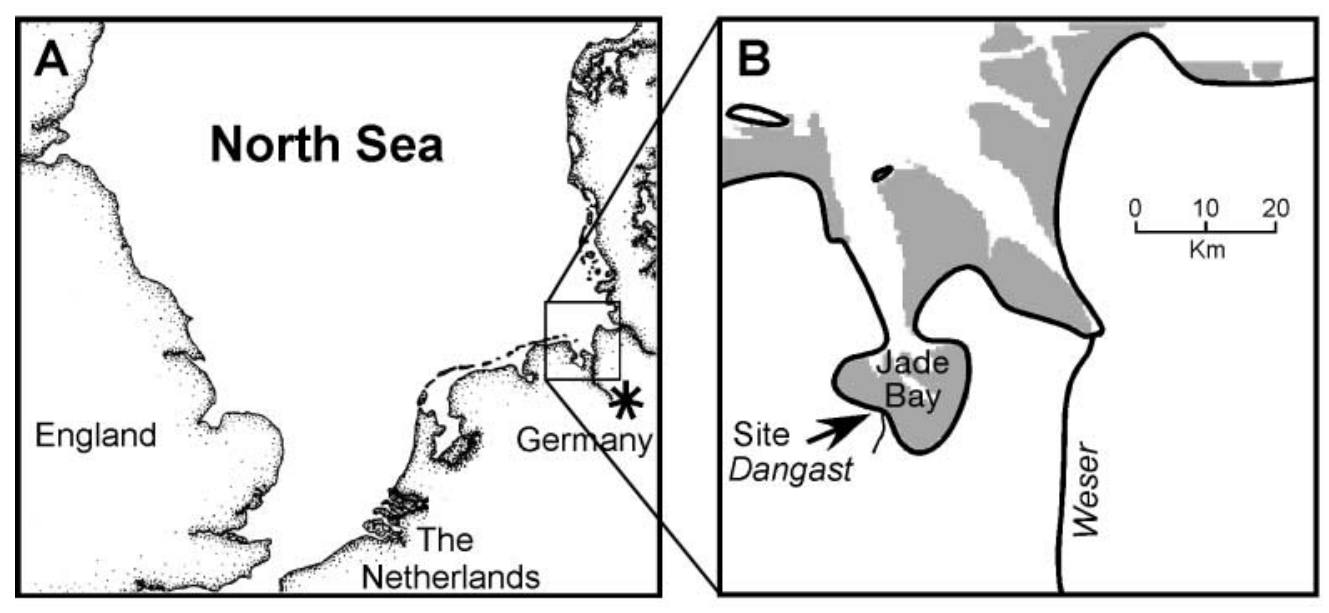

Fig. 1. Location of the sampling site 'Dangast'. (A) The southern coastal area of the North Sea. (*) Bremen. (B) Position of Site Dangast in the Jade Bay is indicated by an arrow. Shading represents areas of intertidal sediment 
The tubes were closed with air-tight rubber stoppers on both ends and transported cool (approx. $4^{\circ} \mathrm{C}$ ) and in the dark to the laboratory for further processing of the sediment cores within about $3 \mathrm{~h}$.

Sediment cores were sliced into the following layers: $0-0.5,0.5-1,1-2,2-3,3-4,4-5,5-10,10-15$ and 15-20 cm (top-down). Sediment samples for enumeration of viable cells (most probable number, MPN) and molecular analysis (denaturing gradient gel electrophoresis, DGGE and fluorescence in situ hybridization, FISH) were taken from the same sediment layers of a single core. For geochemical measurements, parallel cores were used and sliced in $1 \mathrm{~cm}$ layers under inert gas $\left(\mathrm{N}_{2}\right)$ in a temperature-controlled room $\left(4^{\circ} \mathrm{C}\right)$. All cores were taken in close proximity from an area of 1 by $2 \mathrm{~m}$.

Characterization of organic material and sulfur speciation. Pore water contents in the sediments, total carbon (TC) and total inorganic carbon (TIC) were determined as described earlier (Böttcher et al. 2000). Total organic carbon (TOC) contents were obtained from the difference of TC and TIC. Phospholipid fatty acids (PLFA) were extracted essentially as described previously (Bligh \& Dyer 1959). The mild alkaline methanolysis procedure was used to transmethylate the ester linked fatty acids of phospholipids to methyl esters (Palojärvi \& Albers 1998). A sample volume of $2.0 \mu \mathrm{l}$ was injected in a splitless mode onto a fused silica capillary column (Optima-5-MS, Macherey und Nagel). The fatty acid methyl esters (FAME) were identified by the use of a gas chromatography - mass spectrometry (GC-MS) system and quantified with a gas chromatography-flame ionisation detection (GCFID) (GC-Q, Finnigan, and GC-Autosystem, Perkin Elmer). The GC-temperature-program is described elsewhere (Palojärvi \& Albers 1998). Quantification was based on nonadecanoic acid methyl ester as internal standard and identification on authentic FAME standards (Supelco; Biotrend). Biomass was determined by lipid-bound phosphate analysis (Findlay et al. 1989).

The fraction of acid volatile sulfide (AVS) was separated from the wet, $\mathrm{Zn}$-acetate preserved sediment by the reaction with cold $6 \mathrm{~N} \mathrm{HCl}$ containing $\mathrm{SnCl}_{2}$ (Duan et al. 1997) in a stream of nitrogen. The addition of $\mathrm{SnCl}_{2}$ increased the recovery of the AVS fraction within the first $5 \mathrm{~cm}$, but no further influence was observed at greater depths (Böttcher unpubl. data). Sulfur isotope ratios (see below) of the AVS fraction recovered by both methods agreed within $1 \%$ (Böttcher unpubl. data). The sum of (essentially) pyrite and (minor) elemental sulfur (fraction 'Cr-II') was obtained by the distillation with hot acidic $\mathrm{Cr}$ (II)chloride solution (Fossing \& Jørgensen 1989). $\mathrm{H}_{2} \mathrm{~S}$ was trapped as $\mathrm{Ag}_{2} \mathrm{~S}$ in an $\mathrm{AgNO}_{3}$ solution, carefully washed with $10 \% \mathrm{NH}_{3}$ solution and distilled water, dried, and quantified gravimetrically.

For stable sulfur isotope analysis $\left({ }^{34} \mathrm{~S} /{ }^{32} \mathrm{~S}\right)$, sulfate was precipitated from filtered (membrane filter with $0.45 \mu \mathrm{m}$ pore width) Zn-acetate preserved pore water samples as $\mathrm{BaSO}_{4}$, carefully washed and dried. Sulfur isotope ratios of the AVS, Cr-II, and pore water sulfate fractions were measured by combustion isotope-ratio monitoring mass spectrometry (C-irmMS) (Pichlmayer \& Blochberger 1988). Samples were converted to $\mathrm{SO}_{2}$ using a Eurovector elemental analyzer which was connected to a Finnigan MAT Delta ${ }^{+}$gas mass spectrometer via a Finnigan Conflo II split interface. Isotope ratios are given in the $\delta$-notation versus the $\mathrm{SF}_{6}$-based Vienna-Canyon Diablo Troilite (V-CDT) standard (Ding et al. 2001). International standards IAEA-S-1, IAEA-S-2 and IAEA-S-3 were used to calibrate the mass spectrometer. A $\delta^{34} \mathrm{~S}$ value of $21.0 \%$ o was measured for the international barium sulfate standard NBS 127.

Pore waters. Air and pore water temperatures were measured with a digital sensor (GTH 1150 digital thermometer) at the beginning and the end of the sampling session. Pore waters were separated from the sediment sections by centrifugation in closed vessels under inert gas $\left(\mathrm{N}_{2}\right)$. Prior to analyses, pore waters were filtered through membrane filters $(0.45 \mu \mathrm{m}$; Sartorius) and acidified with nitric acid (reagent grade quality) into precleaned polyethylene (PE) bottles. Concentrations of dissolved iron, manganese and sulfate were analyzed after appropriate dilution by means of inductively coupled plasma optical emission spectroscopy (ICP-OES) (Perkin Elmer Optima 3000 XL). Results from a gravimetric quantification of dissolved sulfate as $\mathrm{BaSO}_{4}$ in a parallel core agreed well (Fig. 2). $\mathrm{H}_{2} \mathrm{~S}$ was measured in selected samples preserved with $2 \% \mathrm{ZnCl}_{2}$ solution according to Cline (1969). Salinity of filtered samples was measured with a hand refractometer.

The porewater volatile fatty acid (VFA) concentrations were measured by HPLC as 2-nitrophenyl hydrazine derivates as described by Albert \& Martens (1997). The concentration of butanol was reduced to $1.25 \%$, and the concentration of tetrabutylammonium hydroxide to $1 \mathrm{mM}$ in Solvent A and the concentration of tetradecyltrimethylammonium bromide was reduced to $25 \mathrm{mM}$ in Solvent B, as compared to the original method. The detection limit for glycolate and lactate was $0.2 \mu \mathrm{M}$, for acetate and propionate $0.3 \mu \mathrm{M}$ and for formate $0.6 \mu \mathrm{M}$.

Microsensor measurements. Profiles of oxygen, hydrogen sulfide, and nitrate concentrations at the sediment-water interface were measured in the laboratory with microelectrodes. The determination of oxygen profiles was done with Clark-type $\mathrm{O}_{2}$ sensors with guard cathodes (Revsbech 1989) and calibration was 

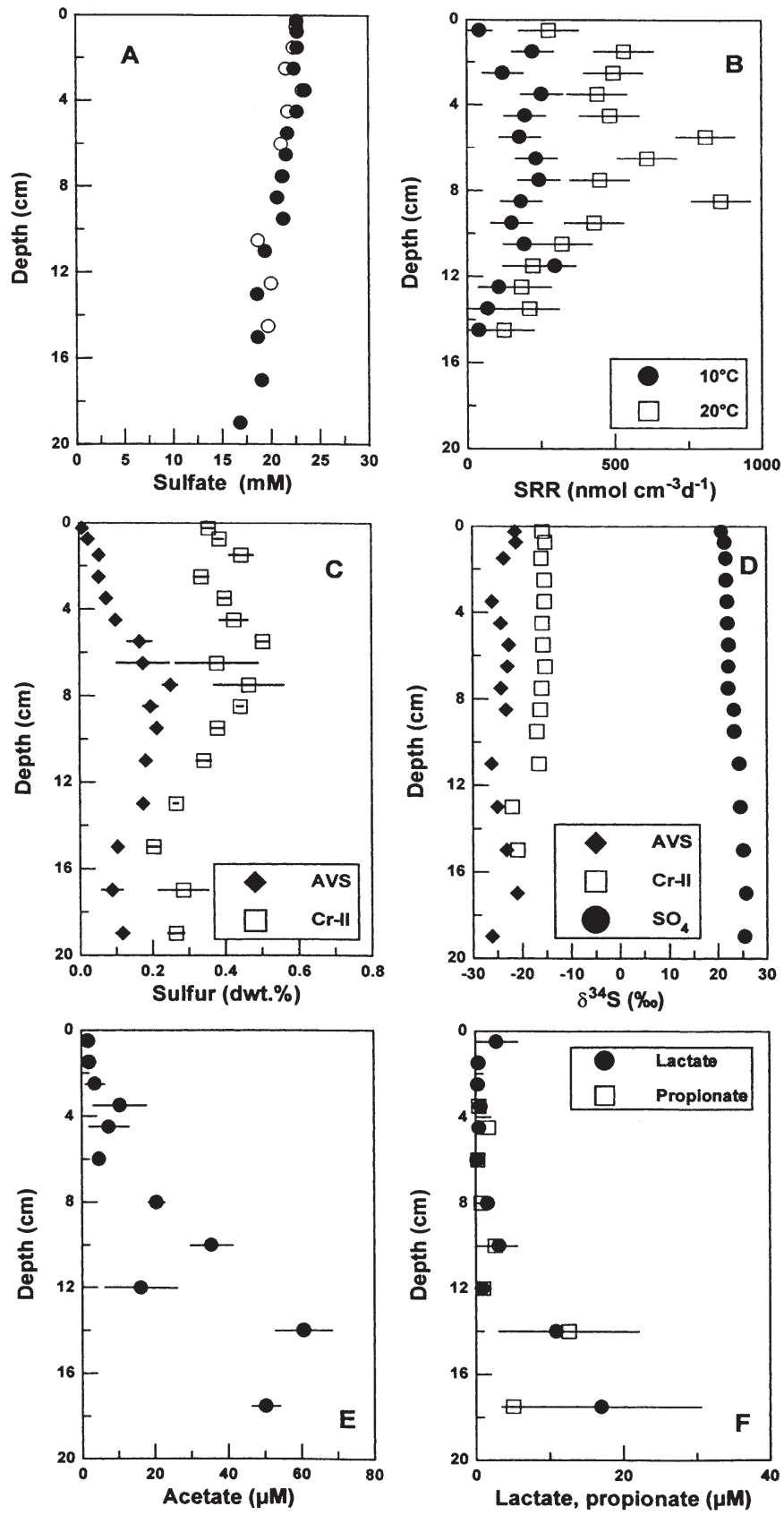

Fig. 2. Biogeochemical analysis of the sediment at Site Dangast. In all cases, the uncertainty of the analytical measurements is within the size of the symbols. (A) Dissolved sulfate (open and solid symbols are from 2 parallel cores). (B) Microbial (SRR) at 2 incubation temperatures approximating the temperate shift during day-night cycles within the sampling period (variance bars result from a comparison with extensive SRR measurements at different temperatures in surface sediments from Site Dangast; Böttcher et al. unpubl.; LlobetBrossa et al. unpubl.). (C) $\mathrm{Cr}$ (II)-reducible sulfur (Cr-II) and acid volatile sulfides (AVS). Variance bars result from duplicate distillations. (D) Isotopic composition of sulfur species. (E) Acetate concentrations (variance bars result from 2 parallel cores). (F) Lactate and propionate (variance bars result from 2 parallel cores) based on calculations described elsewhere (Garcia \& Gordon 1992). Amperometric $\mathrm{H}_{2} \mathrm{~S}$ microsensors were constructed, calibrated and applied as described by Kühl et al. (1998). Nitrate was measured with a microbiosensor in which nitrate and nitrite are reduced to $\mathrm{N}_{2} \mathrm{O}$ by bacteria and $\mathrm{N}_{2} \mathrm{O}$ is detected electrochemically (Larsen et al. 1997).

Sulfate reduction rates (SRR). Bacterial SRR were measured using the whole-core incubation technique with the injection of a carrier-free ${ }^{35} \mathrm{SO}_{4}{ }^{2-}$ tracer (Jørgensen 1978, Fossing \& Jørgensen 1989). After sampling, sediment cores were equilibrated in the laboratory at 10 and $20^{\circ} \mathrm{C}$ for several hours and subsequently incubated with the radiotracer $(\sim 200 \mathrm{kBq}$ per injection at $1 \mathrm{~cm}$ intervals) for $4.5 \mathrm{~h}$ in the dark. Activities counted with a Packard liquid scintillation counter were corrected for blank contributions derived from the counting and the distillation procedures. The apparent activation energy was calculated from an Arrhenius equation using the depth-integrated SRR for 10 and $20^{\circ} \mathrm{C}$.

Nucleic acid extraction and DGGE amplification. Parallel sediment cores were processed to avoid changes in the community composition caused by handling and containment as described before (Rochelle et al. 1994). DNA and RNA of each sediment horizon were extracted from $1.5 \mathrm{ml}$ wet sediment by bead-beating, phenol extraction and isopropanol precipitation as described previously (Sahm \& Berninger 1998). PCR amplification specific for SRB of the $\delta$ subclass of Proteobacteria was carried out with the forward primer SRB385 carrying a GC-clamp and the reverse primer 907 (Sass et al. 1998). DGGE, excision of bands, reamplification, and sequencing were performed as previously described (Muyzer et al. 1996).

DGGE partial sequences were added to an alignment of about 30000 homologous bacterial 16S rRNA genes (Maidak et al. 2002) by using the aligning tool of the ARB program package ${ }^{1}$. Aligned sequences were inserted within a stable tree by using the ARB parsimony tool (Ludwig et al. 1998). Accession numbers of the partial sequences are AF538272 through AF538278, and deposited at GenBank.

FISH and cell counts. Hybridizations, microscopic examination and counting of hybridized cells and total cell counts were performed as previously described (Snaidr et al. 1997, Llobet-Brossa et al. 1998). For each sample, between 700 and 1000 DAPI-stained cells were analyzed and counted; duplicates were carried out for each sample. The oligonucleotide probes used

\footnotetext{
${ }^{1}$ Strunk O, Gross O, Reichel B, May M and 10 others (1998-2002) ARB: a software environment for sequence data. Available at: www.mikro.biologie.tu-muenchen.de
} 
in this study were purchased from Interactiva with Cy3 fluorochrome at the $5^{\prime}$ end. The probes used are listed in Table 1. For FISH of sediment samples, 2 replicate sediment cores were cut and processed as described before (Llobet-Brossa et al. 1998). From MPN tubes that showed growth, aliquots of 1 to $2 \mathrm{ml}$ were withdrawn with $\mathrm{N}_{2}$-flushed syringes. Cells were sedimentated by centrifugation and washed once with $1 \times$ PBS. Subsequent fixation and hybridization were performed as previously described (Snaidr et al. 1997).

Media and enumeration of viable cells by MPN. A defined, bicarbonate-buffered, sulfide-reduced (1 mM) seawater-like mineral medium was used for cultivation experiments (Widdel \& Bak 1992). Na-dithionate at a final concentration of $10 \mu \mathrm{g} \mathrm{ml}^{-1}$ was applied as an additional reductant. Organic substrates were added from concentrated stock solutions. Gaseous substrates $\left(\mathrm{H}_{2} / \mathrm{CO}_{2}\right)$ were supplied by applying an overpressure of $1 \mathrm{~atm}$ to the headspace of the culture tubes.

Viable SRB were enumerated using an MPN technique with liquid media and with agar shakes. Samples from each layer of the sediment core were transferred via a funnel to glass bottles $(250 \mathrm{ml}$ volume) and mixed 1:1 with substrate-free, anoxic media under a steady stream of $\mathrm{N}_{2} / \mathrm{CO}_{2}(90: 10$ [v/v]), yielding approximately $100 \mathrm{ml}$ of homogenate. The bottles were then anoxically sealed with butyl-rubber stoppers and screw caps. These sediment slurries were diluted in steps of $1: 10$ by transferring aliquots to substrate-free, anoxic media under $\mathrm{N}_{2} / \mathrm{CO}_{2}(90: 10$ [v/v]) in

Table 1. Oligonucleotide probes

\begin{tabular}{|c|c|c|c|c|}
\hline Probe & Target & Sequence $\left(5^{\prime}-3^{\prime}\right)$ of probe & $\begin{array}{l}{[\%] \mathrm{FA}^{\mathrm{a}}} \\
\text { in situ }\end{array}$ & Source \\
\hline EUB338 & $\begin{array}{l}\text { Bacteria } \\
\text { 16S rRNA, position }{ }^{\mathrm{b}} 338-355\end{array}$ & GCT GCC TCC CGT AGG AGT & $0-35$ & Amann et al. (1990) \\
\hline Arch915 & $\begin{array}{l}\text { Archaea } \\
\text { 16S rRNA, position 915-935 }\end{array}$ & AG GAA TTG GCG GGG GAG CAC & 35 & Amann et al. (1990) \\
\hline DNMA657 & $\begin{array}{l}\text { Desulfonema sp. } \\
\text { 16S rRNA, position } 657-676\end{array}$ & TTC CGY TTC CCT CTC CCA TA & 35 & Fukui et al. (1999) \\
\hline DSV698 & $\begin{array}{l}\text { Desulfovibrio ( } 16 \text { species) } \\
\text { 16S rRNA, position } 698-717\end{array}$ & GTT CCT CCA GAT ATC TAC GG & 35 & Manz et al. (1998) \\
\hline DSV1292 & $\begin{array}{l}\text { Desulfovibrio (13 species) } \\
\text { 16S rRNA, position } 1292-1310\end{array}$ & CAA TCC GGA CTG GGA CGC & 35 & Manz et al. (1998) \\
\hline DSV407 & $\begin{array}{l}\text { Desulfovibrio ( } 3 \text { species) } \\
\text { 16S rRNA, position } 407-424\end{array}$ & CCG AAG GCC TTC TTC CCT & 50 & Manz et al. (1998) \\
\hline DSD131 & $\begin{array}{l}\text { Desulfovibrio ( } 1 \text { species) } \\
\text { 16S rRNA, position 131-148 }\end{array}$ & CCC GAT CGT CTG GGC AGG & 20 & Manz et al. (1998) \\
\hline DSV214 & $\begin{array}{l}\text { Desulfovibrio/D' microbium } \\
\text { 16S rRNA, position } 214-230\end{array}$ & CAT CCT CGG ACG AA TGC & 10 & Manz et al. (1998) \\
\hline DSS658 & $\begin{array}{l}\text { Desulfosarcina/D' coccus/D' frigus } \\
\text { 16S rRNA, position } 658-675\end{array}$ & TCC ACT TCC CTC TCC CAT & 60 & Manz et al. (1998) \\
\hline DSB985 & $\begin{array}{l}\text { Desulfobacter/D' bacula } \\
\text { 16S rRNA, position 985-1003 }\end{array}$ & CAC AGG ATG TCA AAC CCA G & 20 & Manz et al. (1998) \\
\hline SRB221 & $\begin{array}{l}\text { Desulfobacterium } \\
\text { 16S rRNA, position 221-238 }\end{array}$ & TGC GCG GAC TCA TTC AAA & 35 & Devereux et al. (1992) \\
\hline SRB660 & $\begin{array}{l}\text { Desulfobulbus } \\
\text { 16S rRNA, position 660-679 }\end{array}$ & GAA TTC CAC TTT CCC CTC TG & 60 & Devereux et al. (1992) \\
\hline DSBO224 & $\begin{array}{l}\text { Desulfobotulus } \\
\text { 16S rRNA, position } 224-242\end{array}$ & GGG ACG CGG ACT CAT CCT C & 60 & Manz et al. (1998) \\
\hline DSMA488 & $\begin{array}{l}\text { Desulfovibrio/D'monile } \\
\text { 16S rRNA, position } 488-507\end{array}$ & GCC GGT GCT TCC TTT GGC GG & 60 & Manz et al. (1998) \\
\hline DSR651 & $\begin{array}{l}\text { Desulforhopalus } \\
\text { 16S rRNA, position 651-668 }\end{array}$ & CCC CCT CCA GTA CTC AAG & 35 & Manz et al. (1998) \\
\hline DTM229 & $\begin{array}{l}\text { Desulfotomaculum } \\
\text { 16S rRNA, position 229-246 }\end{array}$ & AAT GGG ACG CGG AXC CAT & 15 & Manz et al. (1998) \\
\hline SVAL428 & $\begin{array}{l}\text { Desulfotalea/D'fustis } \\
\text { 16S rRNA, position } 428-446\end{array}$ & CCA TCT GAC AGG ATT TTA C & 25 & Sahm et al. (1999) \\
\hline NON338 & $\begin{array}{l}\text { None } \\
\text { (negative control) }\end{array}$ & ACT CCT ACG GGA GGC AGC & $0-35$ & Wallner et al. (1993) \\
\hline
\end{tabular}


butyl-rubber sealed glass bottles (volume of bottle was $250 \mathrm{ml}$, total volume of dilution was $100 \mathrm{ml}$ ). The transfer of sediment suspensions between the glass-bottles was carried out with $\mathrm{N}_{2}$-flushed syringes. Prior to transfer, the sediment suspensions were shaken vigorously to achieve optimal mixing. These 'master' dilutions were used to inoculate culture tubes for MPN counts in liquid media. Similarily, 'master' dilutions were prepared for the inoculation of MPN counts in agar shakes. However, in this case, not every single sediment layer was diluted but rather a homogenous mix of the top $5 \mathrm{~cm}$ of the sediment core.

MPN counts in liquid media were carried out in glass tubes $(160 \times 16 \mathrm{~mm})$ sealed with butyl-rubber stoppers and screw caps that contained anoxic media with or without substrate under an $\mathrm{N}_{2} / \mathrm{CO}_{2}$-atmosphere (90:10 [v/v]). Substrates used were as follows: $\mathrm{H}_{2} / \mathrm{CO}_{2}(90: 10$ $[\mathrm{v} / \mathrm{v}]$, applied with $1 \mathrm{~atm}$ to the gas head space); $\mathrm{H}_{2} / \mathrm{CO}_{2}+2 \mathrm{mM}$ acetate; $15 \mathrm{mM}$ formate; $7.5 \mathrm{mM}$ acetate; $5 \mathrm{mM}$ propionate; $5 \mathrm{mM}$ lactate. Each tube contained $9 \mathrm{ml}$ medium and was inoculated with $1 \mathrm{ml}$ from the corresponding 'master' dilution. Three replicates were prepared for each substrate condition. To sustain reduced conditions, $0.5 \mathrm{mM} \mathrm{Na}_{2} \mathrm{~S}$ were added after about $4 \mathrm{wk}$ of incubation. The tubes were incubated at $23^{\circ} \mathrm{C}$ for $10 \mathrm{mo}$. Growth of SRB was determined by measurement of the optical density $(660 \mathrm{~nm})$ and sulfide using the semiquantitative method described by Cord-Ruwisch (1985) and by macroscopic and microscopic examination.

MPN counts in agar shakes were conducted to obtain single colonies. Glass tubes sealed with butyl-rubber stoppers containing approximately $9 \mathrm{ml}$ of anoxic media with molten agar and substrates as described above were prepared as summarized previously for the isolation of SRB (Widdel \& Bak 1992). The tubes were inoculated with $1 \mathrm{ml}$ from the corresponding 'master' dilution. Replicates and incubation conditions were as described above for MPN counts in liquid media. Agar shakes were incubated at $23^{\circ} \mathrm{C}$. Growth was determined by microscopically observing formation of brownish colonies which are typical for SRB. Such colonies were picked by means of finely drawn Pasteur pipettes (Widdel \& Bak 1992) and transferred to liquid medium containing the corresponding substrate.

\section{RESULTS}

\section{Sediment}

Downcore temperatures in the sediments increased from $15.8^{\circ} \mathrm{C}$ at the surface to $17.5^{\circ} \mathrm{C}$ at depth during sampling. The sediments displayed 2 distinct color changes: the oxic upper part was brown, which turned into a darker olive green with some greyish diffuse streaks within the first 1 to $2 \mathrm{~cm}$. At about 9 to $12 \mathrm{cmbsf}$ ( $\mathrm{cm}$ below surface), the sediment turned black. These vertical changes were also reflected by geochemical and biological parameters. The sediment was characterized by bioturbation, and living polychaetes were found down to about $16 \mathrm{cmbsf}$. The first $10 \mathrm{~cm}$ almost completely consisted of mud (clay and silt grain size fraction $<63 \mu \mathrm{m}$; essentially phyllosilicates; Böttcher et al. 2000). An increase in the sand grain fraction was observed below that depth (Böttcher et al. 2000). Correspondingly, the pore water contents decreased continuously with depth. During sampling in June 1999, for instance, a maximum water content of $67 \%$ was observed near the surface $(0.5 \mathrm{~cm}$ depth), which decreased to 52 and $29 \%$ at 10 and $29 \mathrm{~cm}$ depth, respectively. The TOC contents decreased with depth from $3 \%$ dry weight (surface to $8 \mathrm{cmbsf}$ ) to $1 \%$ (16 cmbsf) in parallel with the pore water contents. This covariation is also known from other tidal sediments of the German Wadden Sea (Delafontaine et al. 1996, Böttcher et al. 1998a, 2000, Volkman et al. 2000).

AVS (essentially iron monosulfide) were found in all sections and showed a maximum at around $8 \mathrm{~cm}$ depth (Fig. 2C). The stable sulfur isotopic signature of AVS essentially mirrors that of $\mathrm{H}_{2} \mathrm{~S}$ which is derived from the overall metabolic processes in the sulfur cycle (Böttcher et al. 1998b). The AVS fraction $\left(\delta^{34} \mathrm{~S}\right.$ values between -21.1 and $-26.2 \%$ ) was significantly enriched in the lighter sulfur isotope compared to coexisting pore water sulfate $\left(\delta^{34} \mathrm{~S}\right.$ values between +20.8 and $+25.8 \%$; Fig. 2D). Apparent sulfur isotope enrichment factors between -42 and $-53 \%$ are calculated from the data given in Fig. 2D which are at the upper end or even exceed the results obtained in experiments with pure cultures of SRB (Kaplan \& Rittenberg 1964, Chambers et al. 1975, Bollinger et al. 2001). The isotopic composition of the Cr-II fraction, which consists essentially of pyrite, was more or less constant in the top $11 \mathrm{~cm}\left(\delta^{34} \mathrm{~S}\right.$ of $-16 \pm 1 \%$ ) but decreased at greater depths (Fig. 2D). Sulfur isotope data are within the range reported previously for iron sulfides in intertidal sediments (Chambers 1982, Böttcher et al. 1998a, 2000).

\section{Pore waters}

The salinities of the pore waters during sampling in June 1999 were rather constant with $28 \%$. This corresponds well to earlier mean data (26\%) obtained during sampling on a seasonal base over a 2 yr period (Böttcher unpubl.).

The composition of interstitial waters sensitively mirrors the biogeochemical processes taking place in the sediment. Microsensor measurements revealed oxygen 
and nitrate penetration depths during sampling of 3.1 and $3.6 \mathrm{~mm}$, respectively. No hydrogen sulfide was detected by microsensors in the sediment cores within the first $20 \mathrm{~mm}$. Sub-oxic, non-sulfidic conditions between about $5 \mathrm{~mm}$ down to at least $12 \mathrm{~cm}$ depth were indicated by the presence of dissolved Fe(II) (12 to $120 \mu \mathrm{M}$ ) and $\mathrm{Mn}$ (II) (36 to $63 \mu \mathrm{M}$ ) and sulfide concentrations below $5 \mu \mathrm{M}$. Sulfate concentrations at the sediment-water interface correspond well to the measured salinities, indicating that dilution of seawater with sulfate-poor freshwaters took place in the surface waters of the coastal region. Sulfate remained essentially constant within the first 4 to $5 \mathrm{~cm}$ and decreased further downcore (Fig. 2A), associated with an enrichment in ${ }^{34} \mathrm{~S}$ (Fig. 2D). This is expected for a system in which the consumption of sulfate by bacteria exceeds the supply of sulfate by transport from the sediment-water interface or by reoxidation of sulfide (Hartman \& Nielsen 1969). Despite minor changes in dissolved sulfate, moderate to high microbial SRR were measured with radiotracers through the whole sediment core and showed a maximum in the suboxic zone at around $7 \mathrm{cmbsf}$ (Fig. 2B). An apparent activation energy of $66 \mathrm{~kJ} \mathrm{~mol}^{-1}$ is obtained from the depthintegrated SRRs at 10 and $20^{\circ} \mathrm{C}$. The measured SRR were within the range reported previously for finegrained tidal sediments of the North Sea (Oenema 1990, Böttcher et al. 2000, Kristensen et al. 2000), and a temperature-shift laboratory experiment with surface sediments from Site Dangast (Llobet-Brossa et al. unpubl.).

The concentrations of VFA (acetate, propionate, and lactate; Fig. 2E,F) were determined in the pore waters of 2 sediment cores. In both cases, concentrations of VFA except for acetate were below $5 \mu \mathrm{M}$ in the top $5 \mathrm{~cm}$ of the sediment. Acetate concentration increased with depth to concentrations of about 50 to $60 \mu \mathrm{M}$. Concentrations of glycolate and formate on the other hand did not exceed $5 \mu \mathrm{M}$ throughout the entire core. Elevated concentrations of lactate and propionate ranging between 10 and $30 \mu \mathrm{M}$ were detected in the deepest horizon of 15 to $20 \mathrm{~cm}$. This accumulation of organic acids occurred only below the maximum of the SRR (Fig. 2B,E,F).

\section{PLFA analysis}

In the sediment samples at Site Dangast, 34 PLFA were identified. The profiles of 6 selected PLFA, which were previously described as marker fatty acids for SRB and other anaerobic bacteria (Findlay \& Dobbs 1993), are presented in their relative and absolute abundance (Fig. 3). Within the upper 3 horizons (top $2 \mathrm{~cm}$ of the sediment) relative and absolute values of all 6 selected PLFA increased significantly. In a sediment depth of 2 to $5 \mathrm{~cm}$, only minor variations of the absolute values were observed, whereas in deeper layers a strong decrease occurred. Below $2 \mathrm{~cm}$ depth, the profiles of the absolute values coincided with those of the total biomass, as estimated by the lipid-bound phosphate concentration (data not shown). Therefore, with the exception of $i 17: 1$ and cyc17:0, the relative amounts of the selected PLFA varied only slightly with depth below $2 \mathrm{~cm}$.

\section{DGGE analysis of sediment}

Changes in the diversity of the SRB population with depth were analyzed by DGGE of PCR-amplified 16S rDNA fragments and of the reversely transcribed $16 \mathrm{~S}$ rRNA fragments. In the same sediment sample, the
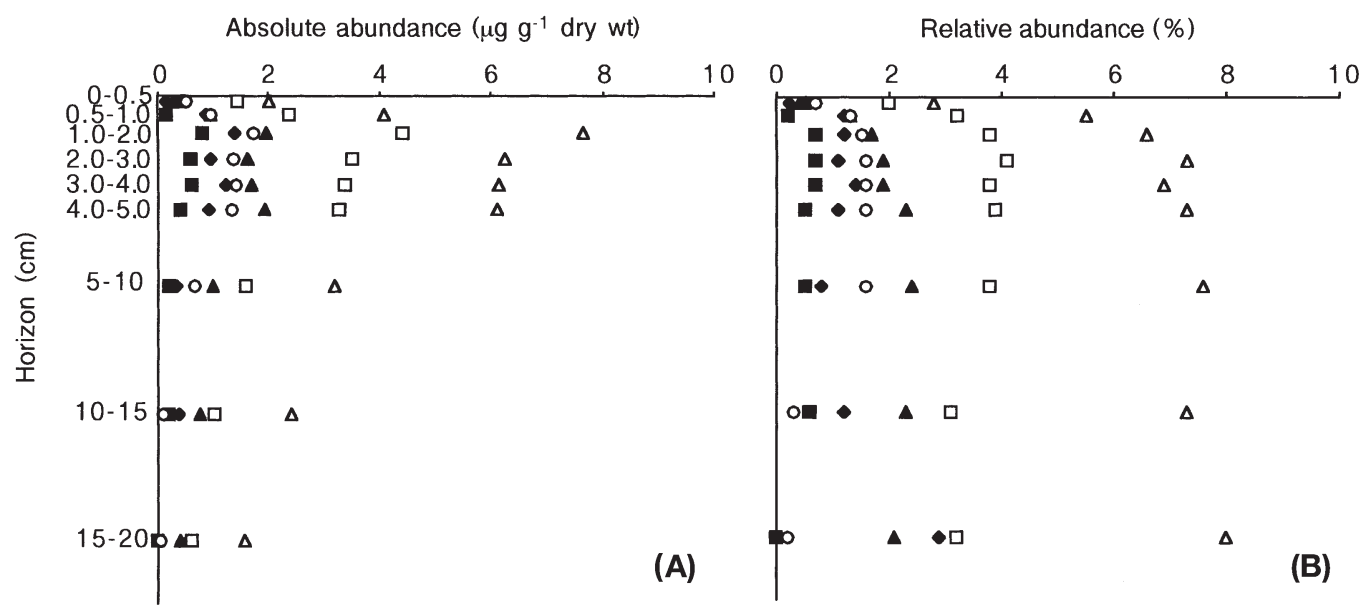

Fig. 3. Depth profiles of selected phospholipid fatty acids (PLFA) of sediment at Site Dangast. Specific PLFAs of sulfate-reducing $(\diamond:$ i17:1, $\mathbf{\square}$ : a17:1 $\boldsymbol{\Delta}: 10 \mathrm{Me} 16: 0)$ and other anaerobic bacteria $(\diamond:$ i15:0; $\square:$ a15:0; $\Delta:$ cyc17:0) from different sediment horizons are plotted. (A) $\mu \mathrm{g}$ values (indicating absolute abundance). (B) Weight percent of total PLFA (indicating relative abundance) 
electrophoretic profiles of the 16S rDNA fragments (Fig. 4A) were more complex than the ones observed after reverse transcription of the 16S rRNA (Fig. 4B).

DGGE of 16S rDNA showed between 6 and 8 bands of different intensities. There were no major changes between different sediment layers, except for the deepest layer at 15 to $20 \mathrm{~cm}$ depth.

DGGE of 16S rRNA showed only 2 to 4 bands in all sediment layers. In contrast to the 16S rDNA-based DGGE, these were not evenly distributed but appeared as distinct patterns. It was not possible to get any PCR product from the deepest layer. As rRNA-based DGGE is influenced by the 'activity-regulated' ribosome contents, this pattern might better indicate the identity and distribution of the active SRB in the sample.

All DGGE bands analyzed by sequencing were shown to originate from members of the $\delta$-subclass of Proteobacteria, the taxonomic group that encompasses most Gram-negative SRB (Fig. 4C). DGGE bands 1 and 2 were affiliated with a sequence similarity of $99 \%$ to Desulfobulbus sp. (accession numbers L40786 and L40785, respectively). DGGE band 3 was found to be closely related to Desulfovibrio caledoniensis (accession number U53465), sharing similarities of $97 \%$. DGGE band 5 was identified as Desulfobacter sp. with 96\% similarity (accession number L40787). DGGE bands 6 and 7 were related with $99 \%$ similarity to Desulfonema limicola (accession number U45990), and to Desulfonema ishimotoei (accession number U45991), respectively. DGGE band 8 had $98 \%$ sequence similarity with Desulfuromonas palmitatis (accession number U28172).

\section{MPN counts of sulfate-reducing bacteria}

A variety of defined substrates was used to meet specific substrate preferences of different SRBs possibly occurring in the studied sediment. The bacterial numbers from MPN counts with liquid media are shown in Table 2.

After about 6 wk of incubation only low cell numbers ranging between $1.1 \times 10^{3}$ and $4.6 \times 10^{5} \mathrm{cells} \mathrm{cm}^{-3}$ could be observed, with the highest cell numbers
A

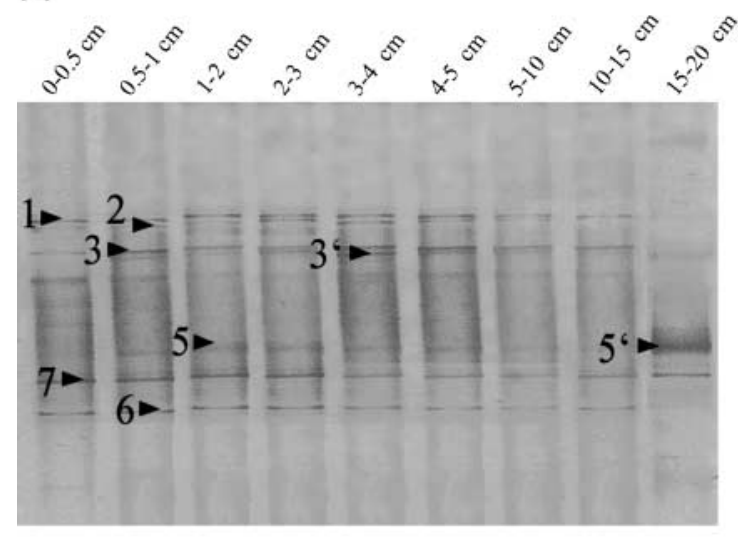

B

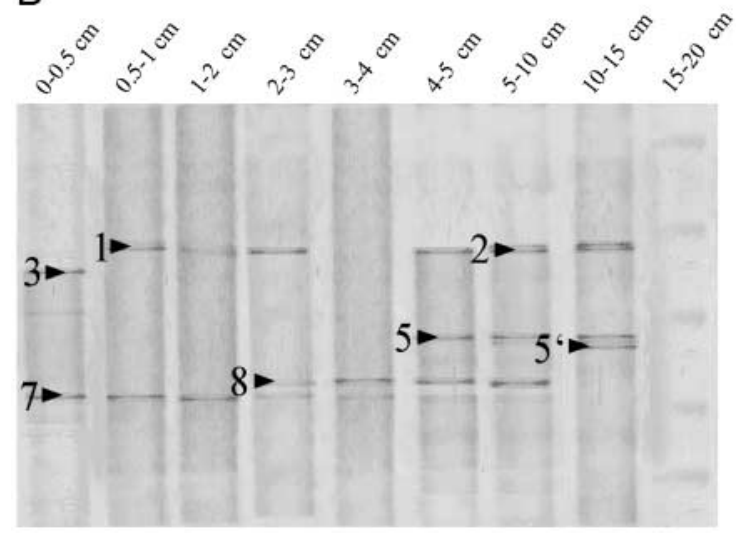

C

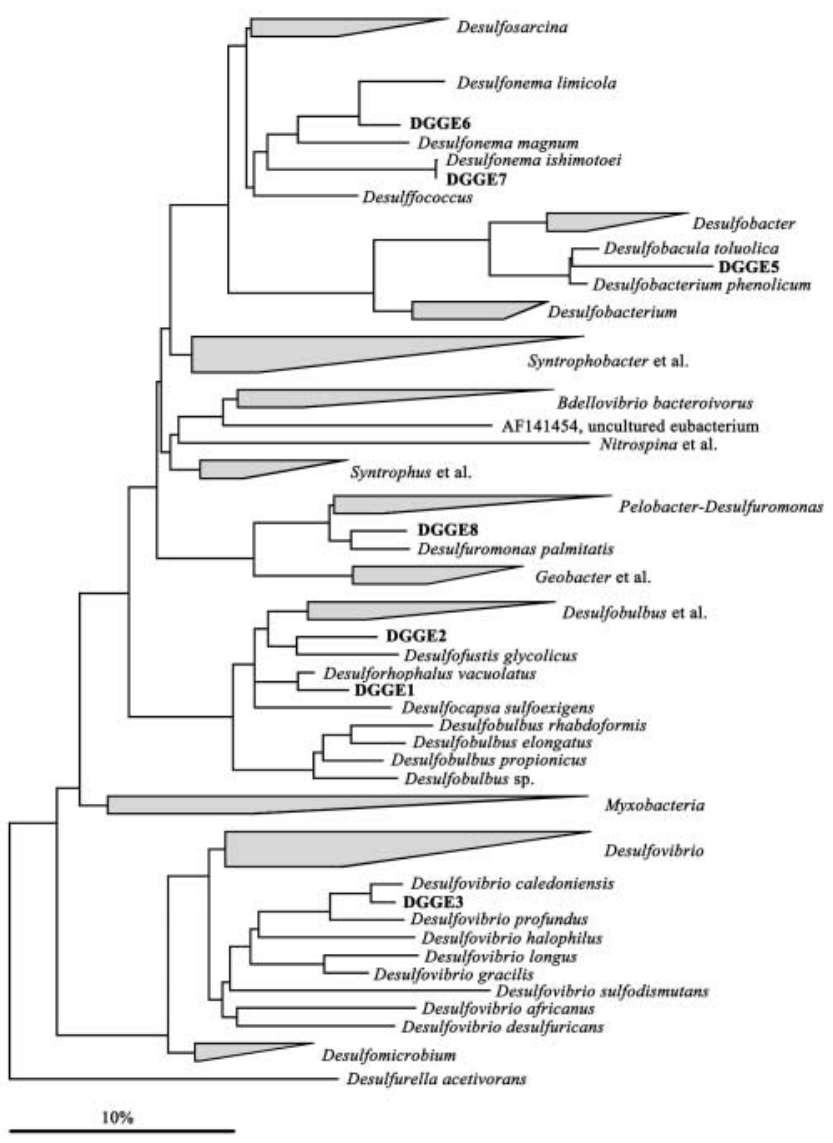

Fig. 4. DGGE analysis of sediment horizons at Site Dangast. (A) DGGE profiles of 16S rDNA. (B) DGGE profiles of reversely transcribed 16S rRNA. (C) Affiliation of sequenced DGGE fragments 
determined in MPN cultures with $\mathrm{H}_{2} / \mathrm{CO}_{2}$ /acetate as substrates. In general, cells grew homogeneously in the medium. These fast-growing SRB appeared to be evenly distributed across a depth profile down to $15 \mathrm{~cm}$. However, cell numbers decreased by about 1 order of magnitude in the lowest horizon of 15 to $20 \mathrm{~cm}$. With all substrates tested, rather similar cell numbers were obtained for all horizons analyzed.
Prolonged incubation (10 mo) of the MPN cultures allowed the detection of slowly growing but more abundant SRB. Counts increased up to $1.1 \times 10^{7}$ cells $\mathrm{cm}^{-3}$. In contrast to the faster growing SRB, here cells did not grow homogeneously distributed in the medium, but rather formed flocs and aggregates, sometimes similar of the cell packages known from Desulfosarcina spp. As with the fast-growing SRBs,

Table 2. Total cell counts (cells $\mathrm{cm}^{-3}$, by MPN ${ }^{\mathrm{a}}$ ) and identification (by FISH, probes as described in Table 1) of sulfate-reducing bacteria (SRB) from different sediment horizons from Site Dangast after 1.5 and 10 mo of incubation at $23^{\circ} \mathrm{C}$ with various substrates typical for SRB. For each sediment horizon analyzed and each substrate used for growth, 2 lines of investigations were followed. First, viable cell numbers were determined by MPN. Second, the phylogenetic affiliation of bacteria grown in the highest MPN dilution was determined by FISH. Results for both investigations are presented in the table. nd: not detected

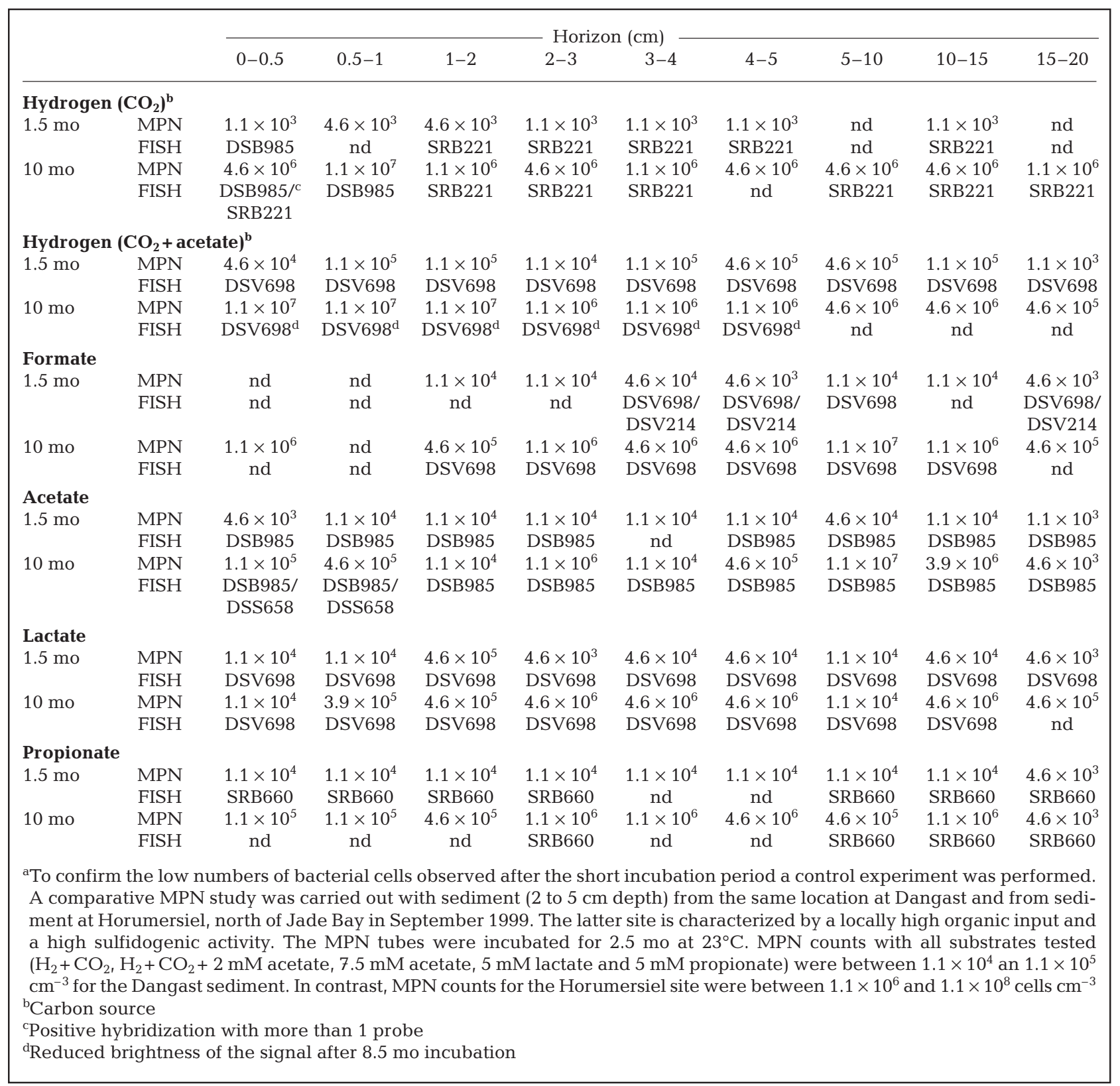


MPN counts indicated that cells were evenly distributed throughout the upper $15 \mathrm{~cm}$ of the sediment profile, with a decrease in cell numbers only in the deepest horizon.

From the highest dilution steps that still showed growth, samples were recovered for FISH analysis, the results of which are summarized in Table 2.

MPN in agar shakes yielded numbers of colony forming units somewhat higher than those observed with MPNs in liquid media (data not shown). Colonies from the highest dilution were transferred to fresh liquid media containing the same substrates as used in the corresponding agar shakes. Subsequent analysis of growth cultures by FISH revealed no other phylogenetic groups as already identified in MPNs with liquid media.

\section{FISH of sediment samples}

Total cell counts of the upper $20 \mathrm{~cm}$ of the sediment were determined microscopically (Table 3). From top to bottom, DAPI counts strongly decreased from $53.9 \times$ $10^{8}$ in the first $\mathrm{cm}$ to $1.0 \times 10^{8}$ cells $\mathrm{cm}^{-3}$ of sediment in the zone below $15 \mathrm{~cm}$.

The microbial community dwelling in Dangast sediments was dominated by Bacteria. In the top $0.5 \mathrm{~cm}$ of the sediment, up to $82.3 \%$ of the total microorganisms hybridized with the probe EUB338 (Table 3). Archaeal and eucaryal counts remained below the detection limit of $0.1 \%$ of the DAPI-stained cells.

Recently, the bacterial probe EUB338 was shown not to detect all members of the domain Bacteria (Daims et al. 1999). Some bacterial phyla, most notably the Planctomycetales and Verrucomicrobia, are missed by this probe. Consequently, total bacterial numbers monitored in this study were most probably underestimated. Initial experiments with the newly designed additional probes EUB338-II and -III (Daims et al. 1999) indicated that this underestimation may amount to $4-10 \%$ of the total microbial community.

Detection rates with the probe EUB338 decreased exponentially over the vertical profile. Thus, not only the absolute cell numbers decreased with depth, but also the percentage of detectable cells with our FISH protocol.

A set of 15 different probes specific for SRB of the $\delta$ subclass of Proteobacteria was tested (Table 1) with sediment samples from Site Dangast. Only 5 of these probes (i.e. SRB221, DSB985, DSR6512, DSS658, and DSV698), gave counts above the detection limit set at $0.1 \%$ of total DAPI counts (Table 3 ). The target groups of the other probes were either not present in high abundance $(>0.1 \%$ of the total cell counts) or not detectable by FISH, e.g. due to a low ribosomal content per cell.

The most abundant SRB present in the sediments were members of the Desulfosarcina-DesulfococcusDesulfofrigus group (probe DSS658) and Desulfovibrio spp. (probe DSV698) with maximum values of $2.9 \pm 0.5$ $\times 10^{8}$ and $2.8 \pm 0.6 \times 10^{8}$ cells $\mathrm{cm}^{-3}$ of sediment, respectively. The counts of these 2 groups decreased strongly with depth to values of $1.0 \pm 0.6 \times 10^{6}$ and $0.6 \pm 0.4 \times$ $10^{6}$ cells $\mathrm{cm}^{-3}$ of sediment at $20 \mathrm{~cm}$ depth, respectively.

SRB detected with the probe DSR651 specific for Desulforhopalus were also counted with decreasing numbers from top to bottom from $1.1 \pm 0.3 \times 10^{8}$ cells $\mathrm{cm}^{-3}$ of sediment in the first $0.5 \mathrm{~cm}$ to $2.7 \pm 0.3 \times 10^{6}$ cells $\mathrm{cm}^{-3}$ sediment between 10 and $15 \mathrm{~cm}$ depth. Cell numbers between 15 and $20 \mathrm{~cm}$ depth were below the detection limit.

Desulfobacter spp. (probe DSB985) were found across the entire sediment profile in relatively low abundance. The cell numbers decreased from $1.1 \pm 0.3$ $\times 10^{7}$ to $0.1 \pm 0.06 \times 10^{5}$ cells $\mathrm{cm}^{-3}$ throughout the sediment. Desulfobacterium spp. targeted with the probe

Table 3. Microbial community structure in different horizons from sediments at Site Dangast studied by FISH. nd: not detected

\begin{tabular}{|c|c|c|c|c|c|c|c|c|}
\hline \multirow{2}{*}{$\begin{array}{l}\text { Horizon } \\
(\mathrm{cm})\end{array}$} & \multicolumn{2}{|c|}{ Cell numbers $\left(\times 10^{8} \mathrm{~cm}^{-3}\right)$} & \multicolumn{6}{|c|}{ — Percentage of hybridized cells ${ }^{\mathrm{a}}($ mean $\pm \mathrm{SD})$} \\
\hline & $\begin{array}{l}\text { DAPI } \\
\text { stain }\end{array}$ & $\begin{array}{c}\text { Probe } \\
\text { EUB } 338\end{array}$ & $\begin{array}{l}\text { Probe } \\
\text { SRB221 }\end{array}$ & $\begin{array}{c}\text { Probe } \\
\text { DSB985 }\end{array}$ & $\begin{array}{c}\text { Probe } \\
\text { DSR651 }\end{array}$ & $\begin{array}{c}\text { Probe } \\
\text { DSS658 }\end{array}$ & $\begin{array}{c}\text { Probe } \\
\text { DSV698 }\end{array}$ & $\begin{array}{c}\text { Sum of SRB } \\
\text { probes }\end{array}$ \\
\hline $0-0.5$ & $53.9 \pm 2.2$ & $44.4 \pm 7.5$ & nd & $0.21 \pm 0.07$ & $2.0 \pm 0.7$ & $2.5 \pm 1$ & $4.3 \pm 0.9$ & 8.6 \\
\hline $0.5-1$ & $53.7 \pm 0.9$ & $37.4 \pm 7.0$ & $0.22 \pm 0.04$ & $0.18 \pm 0.1$ & $1.9 \pm 0.7$ & $4.7 \pm 1.3$ & $5.3 \pm 1.1$ & 12.3 \\
\hline $1-2$ & $56.5 \pm 1.3$ & $39.4 \pm 2.8$ & nd & nd & $2.1 \pm 0.7$ & $5.3 \pm 0.9$ & $3.9 \pm 0.8$ & 11.3 \\
\hline $3-4$ & $33.1 \pm 1.5$ & $15.1 \pm 1.3$ & nd & $0.1 \pm 0.08$ & $2.4 \pm 0.9$ & $2.4 \pm 0.7$ & $4.2 \pm 0.7$ & 9.1 \\
\hline $4-5$ & $25.5 \pm 2.3$ & $9.5 \pm 1.5$ & nd & $0.1 \pm 0.09$ & $1.7 \pm 0.8$ & $3.5 \pm 0.9$ & $6.2 \pm 1.2$ & 11.5 \\
\hline $5-10$ & $17.0 \pm 2.1$ & $4.3 \pm 0.5$ & nd & nd & $0.7 \pm 0.3$ & $2.2 \pm 0.4$ & $3.3 \pm 0.3$ & 6.3 \\
\hline $10-15$ & $9.0 \pm 3.3$ & $1.5 \pm 0.2$ & nd & nd & $0.3 \pm 0.4$ & $1.7 \pm 0.5$ & $1.0 \pm 0.7$ & 3.0 \\
\hline $15-20$ & $1.0 \pm 4.6$ & $0.1 \pm 0.06$ & nd & $0.1 \pm 0.04$ & nd & $1.0 \pm 0.6$ & $0.6 \pm 0.4$ & 1.7 \\
\hline
\end{tabular}

aPercent detection compared to DAPI. Numbers have been corrected by subtracting NON338 counts. Means and SD were calculated from the counts of 2 parallel cores 
SRB221 were only detected in the layers between 1 and $2 \mathrm{~cm}$ depth $\left(1.1 \pm 0.1 \times 10^{7}\right.$ and $8.0 \pm 0.4 \times 10^{6}$ cells $\mathrm{cm}^{-3}$ ).

Maximal numbers of detectable SRB were found within the upper $3 \mathrm{~cm}$ of the sediment (up to $6.6 \pm 1.0 \times$ $10^{8}$ cells $\mathrm{cm}^{-3}$, accounting for 8.6 to $12.3 \%$ of total cells). Below $3 \mathrm{~cm}$ depth, the total number of SRB decreased continuously to a minimal value of $1.7 \pm 0.8$ $\times 10^{6}$ cells $\mathrm{cm}^{-3}$ at 15 to $20 \mathrm{~cm}$ depth (corresponding to $1.7 \%$ of total cells, Table 3 ).

\section{DISCUSSION}

\section{Biogeochemistry of the sediment}

The accumulation of AVS and the sulfur isotopic discrimination between sulfate and the AVS fractions throughout the investigated sediment layers (Fig. 2) are clear indications for the dissimilatory activity of SRB under anaerobic conditions. The isotope enrichment factors observed in the Dangast sediment partly exceed the maximum found in pure cultures (e.g. Bollinger et al. 2001) or experiments with sediment incubations using natural mixed populations (Canfield 2001). This might be due to the activity of sulfate reducers at this site, which have so far not been used in experiments on isotope discrimination. In addition, it is known that $\mathrm{H}_{2} \mathrm{~S}$ is, to a significant portion, reoxidized, so that sulfur species with intermediate oxidation states may be formed (Jørgensen 1982b), and such that bacterial disproportionation of the latter may lead to the formation of ${ }^{32} \mathrm{~S}$-enriched $\mathrm{H}_{2} \mathrm{~S}$ (Canfield et al. 1998, Cypionka et al. 1998, Böttcher et al. 2001). Indeed, bacteria which are able to disproportionate elemental sulfur, for instance, have been enriched from the sediments at Site Dangast and shown experimentally to discriminate sulfur isotopes (Canfield et al. 1998). Therefore, the oxidative part of the sulfur cycle may contribute to the observed overall sulfur isotope effect. Solid phase sulfur with higher oxidation states (essentially pyrite with minor elemental sulfur) were found through the sediment core with depth variations essentially decoupled from the AVS trend (Fig. 2C). Compared to the AVS fraction, the physicochemically more stable phase pyrite from the top $11 \mathrm{~cm}$ was generally enriched in ${ }^{34} \mathrm{~S}$ (Fig. 2D). In the deeper more sandy sediment layers the isotope data of both fractions are close to each other. This may indicate the influence of particle mixing by bioturbation on the pyrite pool in the upper sediment section. Additionally, the pyrite fractions may have preserved a change in the depositional environment and the corresponding near surface sulfur cycle of the Jade Bay sediments due to dyke building activities at the end of the last century (Böttcher et al. unpubl.).
In the sediment depth of 2 to $10 \mathrm{~cm}$, maximal bacterial sulfate reduction occurred, even though its product, dissolved sulfide, accumulated only in limited amounts. Re-oxidation of hydrogen sulfide may be coupled to the reduction of Fe(III) and Mn(IV) compounds, resulting in the formation of sulfur species or sulfate and dissolved Fe(II) and Mn(II) (Burdige 1993, Moeslund et al. 1994, Thamdrup et al. 1994, Böttcher \& Thamdrup 2001). Therefore, dissolved Fe(II) and Mn(II) may originate from both microbial and chemical reduction of the metal oxyhydroxides. Hydrogen sulfide can also react with iron compounds to form iron sulfides. In this suboxic part of the sediment a maximum in SRR coincided with highest TOC contents; only at greater depth did a parallel decrease of both parameters occur. The observed decrease in pore water content with sediment depth is due to changes in the sedimentological and mineralogical properties of the sediment caused by a mixing of minerals of the mud fraction with increasing amounts of the sand grain fraction (essentially quartz). In contrast to quartz, phyllosilicate minerals, and especially smectite, are able to adsorb significant amounts of organic matter (Keil et al. 1994, Mayer 1994). In addition, stable carbon isotope measurements on TOC at Site Dangast have shown that the labile fraction of organic matter, which is of marine origin, decreases with depth due to the preferential biodegradation of marine organic matter (Böttcher et al. 2000).

The actual substrates of SRB are small molecules like VFA. Therefore, microbial sulfate reduction depends on the activity of fermentative bacteria which are able to degrade polymeric substances to such small molecules (e.g. Sørensen et al. 1981, Christensen 1984). Consequently, the SRR is also linked to the production rate of VFA. The concentrations of VFA in interstitial waters depend on the balance of production and consumption rates. The reactions responsible for the quantitative balance in different environments, however, are not fully understood. In the present study, high concentrations of acetate and lactate coincide with low SRR (Fig. 2). This is in agreement with observations by Novelli et al. (1988) and Holmer \& Kristensen (1996). We suggest that the production rates of VFA are balanced by SRR in the top sediments, but increase relatively further downcore.

\section{Sulfate-reducing bacteria}

Specific PLFAs have often been described as biomarkers for different physiological groups of organisms (Findlay \& Dobbs 1993). The iso-branched, unsaturated fatty acid i17:1 may serve as marker fatty acid for members of the genus Desulfovibrio, whereas the 
anteiso-branched fatty acid a17:1 has only been detected in significant amounts in Desulfosarcina variabilis and Desulfococcus multivorans (Vainshtein et al. 1992, Kohring et al. 1994). The branched fatty acid 10Me16:0 has been found in members of the family Desulfobacteriaceae (Taylor \& Parkes 1983, Dowling et al. 1986, Kohring et al. 1994, Kuever et al. 2001) and has often been used as a biomarker for SRB in marine sediments (Findlay \& Dobbs 1993). The selected fatty acids i15:0, a15:0 and cyc17:0 were previously suggested as biomarkers for anaerobic bacteria, including SRB (Guckert et al. 1985, Findlay et al. 1990, Findlay \& Dobbs 1993). The absolute and relative abundance of these PLFAs, with highest values in the sediment layers between 1 and $5 \mathrm{~cm}$ depth are in the range of those reported previously for marine sediments (Guckert et al. 1985, Findlay \& Dobbs 1993, Findlay \& Watling 1998). The highest absolute values of these biomarkers indicate highest cell numbers of SRB and other anaerobic bacteria in these sediment layers. The profiles of the relative amounts of these PLFAs indicate that the share of this group within the total microbial community increased within the top $2 \mathrm{~cm}$ and remained constant below that layer. It should be noted, however, that an absolute quantification of SRB by PLFA analysis is not possible, since the cellular fatty acid composition of SRB can be influenced by carbon sources, temperature or growth phase, as demonstrated with pure cultures (Taylor \& Parkes 1983, Dowling et al. 1986, Aeckersberg et al. 1998, Könneke 2001).

DGGE analysis was carried out to define phylogenetic diversity of SRB based on 16S rDNA (Fig. 4A) and the active fraction of the SRB community based on 16S rRNA (Fig. 4B). Phylogenetic identification of the most prominent DGGE bands showed diverse affiliation within the $\delta$-subclass of Proteobacteria (Fig. 4C). Interestingly, most sequences were closely related to SRB originating from marine environments, e.g. Desulfonema ishimotoei (isolated from Dangast, the present study area, see Fukui et al. 1999) and Desulfobacula toluolica (isolated from Eel Pond, Woods Hole, USA, see Rabus et al. 1993). A similar electrophoretic pattern of amplified 16S rDNA in the upper $15 \mathrm{~cm}$ of the sediment indicated an even distribution of SRB. However, DGGE analysis of reversely transcribed $16 \mathrm{~S}$ rRNA showed an uneven distribution across the sediment profile. Reversely transcribed 16S rRNA indirectly reflect the ribosome content of cells, allowing active cells to be identified. Based on 16S rDNA profiling, DGGE band 5 (Fig. 4A) is evenly distributed throughout the studied sediment horizons. In contrast, this band could only be detected in the lower part (below $3 \mathrm{~cm}$ ) of the sediment, if monitored by $16 \mathrm{~S}$ rRNA-based DGGE profiling (Fig. 4B). This could indicate that the Desulfobacter/Desulfobacula type SRB represented by DGGE band 5 (Fig. 4C) are most active in the lower part of the sediment, even though they are also present in the upper part. The opposite was observed for DGGE band 3, representing Desulfovibrio type SRB. Overall, different SRB represented by 8 DGGE bands were phylogenetically identified. Except for 1 sequence (DGGE band 6), all of them were also identified as active members of the SRB community.

Viable SRB obtained with a variety of substrates were quantified and identified by combining MPN and FISH studies. Regardless of the MPN substrates used or the length of the incubation period, an even distribution of cells throughout the sediment profile was observed (Table 2). Identification of SRB in highest dilution showing growth was performed with FISH (Table 2). With respect to the individual substrates added to the MPN cultures, results were in good agreement with the nutritional properties of known SRB. For example, cultures with either lactate or $\mathrm{H}_{2} / \mathrm{CO}_{2}$ /acetate known as substrates typical for Desulfovibrio were indeed dominated by members of this species. In addition, $\mathrm{H}_{2} / \mathrm{CO}_{2}$, requiring chemolithoautotrophic metabolism as known from Desulfobacterium autotrophicum (Brysch et al. 1987), yielded predominantly members of this genus. MPN cultures with acetate were dominated by members of the genera Desulfobacter and/or Desulfobacula, known to possess the capacity for complete oxidation of acetate (Rabus et al. 2000). During incubation the SRB population changed under most conditions (i.e. with different substrates used and sampling depths tested). After a short incubation time of about $6 \mathrm{wk}$ a more rapidly growing population of less abundant cells developed. The more abundant population required a prolonged incubation time of about 10 mo. It should be noted that SRB of this population type did not grow homogeneously in the culture medium but formed flocs, which may result in an underestimation of the actual cell numbers determined with MPN (Table 2) as compared to FISH (Table 3).

The examination by FISH of the microbial community in the sediment showed that SRB account for a significant part of the detectable Bacteria. Up to $6.6 \pm 1.0 \times 10^{8}$ cells $\mathrm{cm}^{-3}$ were identified as SRB. Based on this number and SRR, the cellular SRR in the Dangast sediment was calculated as $1 \mathrm{fmol} \mathrm{SO}_{4}{ }^{2-} \mathrm{cell}^{-1} \mathrm{~d}^{-1}$, agreeing with recent reports from other natural settings (Sahm et al. 1999, Böttcher et al. 2000, Ravenschlag et al. 2000). Interestingly, these in situ values are at the lower end of cellular SRR determined for pure cultures of various SRB (Canfield et al. 2000). These low cellular rates are also in agreement with the observed sulfur isotopic discrimination of iron monosulfides and sulfate (Fig. 2D). The cell numbers determined by FISH (Table 3) were always higher than the 
numbers of viable SRB observed using MPN (Table 2). A similar discrepancy between MPN counts and for instance DAPI-based cell counts have been described (Sievert et al. 1999). The absolute cell numbers might be underestimated since typically less than $1 \%$ of all bacteria in natural habitats may be accessible by current cultivation methods (Amann et al. 1995). In addition, floc formation and clumping of cells may also lead to an underestimation, since the MPN evaluation assumes that only a single cell is required to initiate growth at the highest dilution.

The 2 most abundant groups of SRB identified by FISH were the Desulfovibrio group and the Desulfosarcina-Desulfococus-Desulfofrigus group, which is in agreement with low concentrations of lactate and acetate in the upper layers of the sediment. Therefore these 2 groups - at the sampling time point in June 1999 - were the key populations for the terminal mineralization step in the anaerobic zone of the temperate intertidal mud flat. The Desulfovibrio group was also identified by PLFA, MPN and DGGE analysis. However, the Desulfosarcina-Desulfococus-Desulfofrigus group could only be also identified by PLFA, but not when MPN and DGGE were applied. Possible explanations could be that the cultivation conditions used do not select for SRB affiliating with this group, and that the primers used for DGGE are not targeting this group (Ravenschlag et al. 2000). Such discrepancies caused by technical limitations are known in molecular ecology (for summary refer to Head et al. 1998). Therefore, in addition to a continuous improvement of molecular tools, fully integrated approaches are necessary to obtain a comprehensive overview of the microbial communities in complex environmental samples.

Acknowledgements. We wish to thank B. Schnetger and H. Lüschen (ICBM Oldenburg) for technical support, and S. Fleischer, K. Neumann, J. Botzenhardt, C. Probian and D. Lange (MPI Bremen) for assistance in the laboratory. The authors are indebted to $\mathrm{T}$. Kjaer for providing the nitrate biosensors, to G. Eickert, A. Eggers, and V. Hübner for constructing $\mathrm{O}_{2}$ and $\mathrm{H}_{2} \mathrm{~S}$ microsensors and to M. Mußmann for help with phylogenetic analysis. H.-J. Brumsack (ICBM Oldenburg) kindly allowed access to analytical facilities. We are grateful to B. B. Jørgensen and F. Widdel for reading the manuscript and constructive suggestions. The manuscript was further improved by the comments of 3 anonymous reviewers. We thank the Nationalparkverwaltung Niedersächsisches Wattenmeer for permission to work in the tidal flats. The study was supported by the Max Planck Society, Munich, and by the German Science Foundation during DFG-Research Group 'Bio Geo Chemistry of the Wadden Sea'.

\section{LITERATURE CITED}

Aeckersberg F, Rainey F, Widdel F (1998) Growth, natural relationships, cellular fatty acids and metabolic adaptations of sulfate-reducing bacteria that utilize long-chain alkanes under anoxic conditions. Arch Microbiol 170: 361-369

Albert D, Martens CS (1997) Determination of low-molecularweight organic acid concentrations in seawater and porewater samples via HPLC. Mar Chem 56:27-37

Amann R, Binder BJ, Olson RJ, Chisholm SW, Devereux R, Stahl DA (1990) Combination of 16S rRNA-targeted oligonucleotide probes with flow cytometry for analyzing mixed microbial populations. Appl Environ Microbiol 56: 1919-1925

Amann R, Ludwig W, Schleifer KH (1995) Phylogenetic identification and in situ detection of individual microbial cells without cultivation. Microbiol Rev 59:143-169

Berner R (1982) Burial of organic carbon and pyrite sulfur in the modern ocean: its geochemical and environmental significance. Am J Sci 282:451-473

Bligh EG, Dyer WJ (1959) A rapid method of total lipid extraction and purification. Can J Biochem Physiol 37:911-917

Bollinger C, Schroth MH, Bernasconi SM, Kleikemper J, Zeyer J (2001) Sulfur isotope fractionation during microbial sulfate reduction by toluene-degrading bacteria. Geochim Cosmochim Acta 65:3289-3298

Böttcher ME, Thamdrup B (2001) Anaerobic sulfide oxidation and stable isotope fractionation associated with bacterial sulfur disproportionation in the presence of $\mathrm{MnO}_{2}$. Geochim Cosmochim Acta 65:1573-1581

Böttcher ME, Oelschläger B, Höpner T, Brumsack HJ, Rullkötter J (1998a) Sulfate reduction related to the early diagenetic degradation of organic matter and 'black spot' formation in tidal sandflats of the German Wadden Sea: stable isotope $\left({ }^{13} \mathrm{C},{ }^{34} \mathrm{~S},{ }^{18} \mathrm{O}\right)$ and other geochemical results. Org Geochem 29:1517-1530

Böttcher ME, Smock AM, Cypionka H (1998b) Sulfur isotope fractionation during experimental precipitation of iron (II) and manganese (II) sulfide at room temperature. Chem Geol 146:127-134

Böttcher ME, Hespenheide B, Llobet-Brossa E, Beardsley C and 6 others (2000) The biogeochemistry, stable isotope geochemistry, and microbial community structure of a temperate intertidal mudflat: an integrated study. Cont Shelf Res 20:1749-1769

Böttcher ME, Thamdrup B, Vennemann T (2001) Oxygen and sulfur isotope fractionation during anaerobic bacterial disproportionation of elemental sulfur. Geochim Cosmochim Acta 10:1601-1609

Bowman J, Rea SM, McCammon SA, McMeekin TA (2000) Diversity and community structure within anoxic sediment from marine salinity meromictic lakes and a coastal meromictic marine basin, Vestfold Hills, Eastern Antartica. Environ Microbiol 2:227-237

Brysch K, Schneider C, Fuchs G, Widdel F (1987) Lithoautotrophic growth of sulfate-reducing bacteria, and description of Desulfobacterium autotrophicum gen. nov., sp. nov. Arch Microbiol 148:264-274

Burdige D (1993) Biogeochemistry of manganese and iron reduction in marine sediments. Earth Sci Rev 35:249-284

Canfield DE (2001) Isotope fractionation by natural populations of sulfate-reducing bacteria. Geochim Cosmochim Acta 65:1117-1124

Canfield DE, Thamdrup B, Fleischer S (1998) Isotope fractionation and sulfur metabolism by pure and enrichment cultures of elemental sulfur-disproportionating bacteria. Limnol Oceanogr 43:253-264

Canfield DE, Habicht K, Thamdrup B (2000) The Archean sulfur cycle and the early history of atmospheric oxygen. Science 288:658-661

Chambers LA (1982) Sulfur isotope study of a modern inter- 
tidal environment, and the interpretation of ancient sulfides. Geochim Cosmochim Acta 46:721-728

Chambers LA, Trudinger P, Smith J, Burns M (1975) Fractionation of sulfur isotopes by continuous cultures of Desulfovibrio desulfuricans. Can J Microbiol 21:1602-1607

Christensen D (1984) Determination of substrates oxidized by sulfate reduction in intact cores of marine sediment. Limnol Oceanogr 29:189-192

Cline J (1969) Spectrophotometric determination of hydrogen sulfide in natural waters. Limnol Oceanogr 14:454-458

Cord-Ruwisch R (1985) A quick method for the determination of dissolved and precipitated sulfides in cultures of sulfate-reducing bacteria. J Microbiol Methods 4:33-36

Cypionka H, Smock A, Böttcher ME (1998) A combined pathway of sulfur compound disproportionation in Desulfovibrio desulfuricans. FEMS Microbiol Lett 166:181-186

Daims H, Bruhl A, Amann R, Schleifer KH, Wagner M (1999) The domain-specific probe EUB338 is insufficient for the detection of all Bacteria: development and evaluation of a more comprehensive probe set. Syst Appl Microbiol 22: 434-444

Delafontaine M, Bartholomä A, Flemming B, Kurmis R (1996) Volume-specific dry POC mass in surficial intertidal sediments: a comparison between biogenic muds and adjacent sand flats. Senckenb Marit 26:167-178

Devereux R, He SH, Doyle CL, Orkland S, Stahl DA, LeGall J, Whitman WB (1990) Diversity and origin of Desulfovibrio species: phylogenetic definition of a family. J Bacteriol 172:3609-3619

Devereux R, Kane MD, Winfrey J, Stahl DA (1992) Genusand group-specific hybridization probes for determinative and environmental studies of sulfate-reducing bacteria. Syst Appl Microbiol 15:601-609

Devereux R, Winfey MR, Winfrey J, Stahl DA (1996) Depth profile of sulfate-reducing bacterial ribosomal RNA and mercury methylation in an estuarine sediment. FEMS Microbiol Ecol 20:23-31

Ding T, Valkiers H, Kipphardt P, Bièvre P, Taylor PDP, Gonfiantini R, Krouse R (2001) Calibrated sulfur isotope abundance ratios of three IAEA sulfur isotope reference materials and V-CDT with a reassessment of the atomic weight of sulfur. Geochim Cosmochim Acta 65:2433-2437

Dowling NJE, Widdel F, White DC (1986) Phospholipid esterlinked fatty acid biomarker of acetate-oxidizing sulphatereducers and other sulphide-forming bacteria. J Gen Microbiol 132:1815-1825

Duan WM, Coleman ML, Pye K (1997) Determination of reduced sulphur species in sediments - an evaluation and modified technique. Chem Geol 141:185-194

Fenchel T, King GM, Blackburn T (1998) Bacterial biogeochemistry: the ecophysiology of mineral cycling, 2nd edn. Academic Press, San Diego

Findlay RH, Dobbs FC (1993) Quantitative description of microbial communities using lipid analysis. Handbook of methods in aquatic microbial ecology. Lewis Publishers, Boca Raton, p 271-284

Findlay RH, Watling L (1998) Seasonal variation in the structure of a marine benthic microbial community. Microbiol Ecol 36:23-30

Findlay RH, King GM, Watling L (1989) Efficiency of phospholipid analysis in determining microbial biomass in sediments. Appl Environ Microbiol 55:2888-2893

Findlay RH, Trexler MB, Guckert JB, White DC (1990) Laboratory study of disturbance in marine sediments: response of a microbial community. Mar Ecol Prog Ser 62:121-133

Fossing H, Jørgensen B (1989) Measurement of bacterial sulfate reduction in sediments: evaluation of a single- step chromium reduction method. Biogeochemistry 8: 205-222

Froelich PN, Klinkhammer GP, Benner ML, Luedtke NA and 6 others (1979) Early oxidation of organic matter in pelagic sediments of the eastern equatorial Atlantic: suboxic diagenesis. Geochem Cosmochim Acta 43:1075-1090

Fukui M, Teske A, Aßmus B, Muyzer G, Widdel F (1999) Physiology, phylogenetic relationships, and ecology of filamentous sulfate-reducing bacteria (genus Desulfonema). Arch Microbiol 172:193-203

Garcia HE, Gordon LI (1992) Oxygen solubility in seawaterbetter fitting equations. Limnol Oceanogr 37:1307-1312

Gibbs RJ (1981) Sites of river derived sedimentation in the ocean. Geology 9:77-80

Guckert JB, Antworth CP, Nichols PD, White DC (1985) Phospholipid, ester-linked fatty acid profiles as reproducible assays for changes in prokaryotic community structure of estuarine sediments. FEMS Microbiol Ecol 31:147-158

Hartmann M, Nielsen H (1969) $\delta^{34}$ S-Werte in rezenten Meeressedimenten und ihre Deutung am Beispiel einiger Sedimentprofile aus der westlichen Ostsee. Geol Rundschau 58:621-655

Head IM, Saunders JR, Pickup RW (1998) Microbial evolution, diversity, and ecology: a decade of ribosomal RNA analysis of uncultivated microorganisms. Microb Ecol 35: $1-21$

Holmer M, Kristensen E (1996) Seasonality of sulfate reduction and pore water solutes in a marine fish farm: the importance of temperature and sedimentary organic matter. Biogeochemistry 32:15-39

Irion G (1994) Morphological, sedimentological and historical evolution of the Jade Bay, southern North Sea. Senckenb Marit 24:171-186

Jørgensen BB (1978) A comparison of methods for the quantification of bacterial sulfate reduction in coastal marine sediments. I. Measurements with radiotracer techniques. Geomicrobiol J 1:11-27

Jørgensen BB (1982a) Mineralization of organic matter in the sea bed-the role of sulphate reduction. Nature 296: 643-645

Jørgensen BB (1982b) Ecology of the bacteria of the sulphur cycle with special reference to anoxic-oxic interface environments. Phil Trans R Soc Lond Ser B 298:543-561

Kaplan I, Rittenberg S (1964) Microbiological fractionation of sulphur isotopes. J Gen Microbiol 34:195-212

Keil R, Martlucan D, Prahl F, Hedges J (1994) Sorptive preservation of labile organic matter in marine sediments. Nature 370:549-552

King GM (2001) Radiotracer assays (S-35) of sulfate reduction rates in marine and freshwater sediments. Methods Microbiol 30:489-500

Kohring LL, Ringelberg DB, Devereux R, Stahl DA, Mittelman MW, White DC (1994) Comparison of phylogenetic relationships based on phospholipid fatty acid profiles and ribosomal RNA sequence similarities among dissimilatory sulfate-reducing bacteria. FEMS Microbiol Lett 119: 303-308

Könneke M (2001) Untersuchung der zellulären Fettsäuren von sulfatreduzierenden Bakterien aus kalten, marinen Sedimenten. PhD thesis, Universität Bremen

Kristensen E, Bodenbender J, Jensen M, Rennenberg H, Jensen K (2000) Sulfur cycling of intertidal Wadden Sea sediments (Konigshafen, Island of Sylt, Germany): sulfate reduction and sulfur gas emission. J Sea Res 43:93-104

Kuever J, Könneke M, Galuschko A, Drzyzga O (2001) Reclassification of Desulfobacterium phenolicum as 'Desulfobacula phenolica', comb. nov. and description of 
strain Sax as Desulfotignum balticum gen. nov., sp. nov. Int J Syst Evol Microbiol 51:171-177

Kühl M, Steuckart C, Eickert G, Jeroschewski P (1998) A $\mathrm{H}_{2} \mathrm{~S}$ microsensor for profiling biofilms and sediments: application in an acidic lake sediment. Aquat Microb Ecol 15: 201-209

Larsen LH, Kjaer T, Revsbech NP (1997) A microscale $\mathrm{NO}_{3}$ biosensor for environmental applications. Anal Chem 69: 3527-3531

Llobet-Brossa E, Rosselló-Mora R, Amann R (1998) Microbial community composition of Wadden Sea sediments as revealed by fluorescence-in-situ-hybridization. Appl Environ Microbiol 64:2691-2696

Ludwig W, Strunk O, Klugbauer S, Klugbauer N, Weizenegger M, Neumaier J, Bachleitner M, Schleifer KH (1998) Bacterial phylogeny based on comparative sequence analysis. Electrophoresis 19:554-568

Maidak BL, Cole JR, Lilburn TG, Parker CT and 8 others (2002) The RDP (Ribosomal Database Project) continues. Nucleic Acids Res 29:173-174

Manz W, Eisenbrecher M, Neu TR, Szewzyk U (1998) Abundance and spatial organization of Gram-negative sulfatereducing bacteria in activated sludge investigated by in situ probing with specific 16S rRNA targeted oligonucleotides. FEMS Microbiol Ecol 25:43-61

Mayer L (1994) Relationships between mineral surfaces and organic carbon concentrations in soils and sediments. Chem Geol 114:347-363

Moeslund L, Thamdrup B, Jørgensen BB (1994) Sulfur and iron cycling in a coastal sediment: radiotracer studies and seasonal dynamics. Biogeochemistry 27:129-152

Muyzer G, Hottenträger S, Teske A, Wawer C (1996) Denaturing gradient gel electrophoresis of PCR-amplified 16S rDNA - a new molecular approach to analyse the genetic diversity of mixed microbial communities,. In: Akkermans ADL, van Elsas JD, de Bruijn FJ (eds) Molecular microbial ecology manual, 2nd edn. Kluwer Academic Publishers, Dordrecht, p 3.4.4.1-3.4.4.22

Novelli PC, Michelson AR, Scranton MI, Banta GT, Hobbie JE, Howarth RW (1988) Hydrogen and acetate cycling in two sulfate reducing sediments: Buzzards Bay and Town Cove, Mass. Geochim Cosmochim Acta 52:2477-2486

Oenema O (1990) Sulfate reduction in fine-grained sediments in the Eastern Scheldt, southwest Netherlands. Biogeochemistry 9:53-74

Palojärvi A, Albers BP (1998) Extraktion und Bestimmung membrangebundener Phospholipidfettsäuren. In: Remde P, Tipmann P (eds) Mikrobiologische Charakterisierung aquatischer Sedimente. R. Oldenbourg Verlag, München, p 187-196

Pichlmayer F, Blochberger K (1988) Isotopenhäufigkeitsanalyse von Kohlenstoff, Stickstoff und Schwefel mittels Gerätekopplung Elementaranalysator-Massenspektrometer. Fresenius. Z Anal Chem 33:196-201

Rabus R, Nordhaus R, Ludwig W, Widdel F (1993) Complete oxidation of toluene under strictly anoxic conditions by a new sulfate-reducing bacterium. Appl Environ Microbiol 59:1444-1451

Rabus R, Hansen T, Widdel F (2000) Dissimilatory sulfate- and sulfur-reducing prokaryotes. In: Dworkin M, Falkow S, Rosenberg E, Schleifer KH, Stackebrandt E (eds), The prokaryotes: an evolving electronic resource for the microbiological community. Springer Science Online, Heidelberg (www.prokaryotes.com)

Ravenschlag K, Sahm K, Pernthaler J, Amann R (1999) High bacterial diversity in permanently cold marine sediments. Appl Environ Microbiol 65:3982-3989
Ravenschlag K, Sahm K, Knoblauch C, Jørgensen BB, Amann R (2000) Community structure, cellular rRNA content and activity of sulfate-reducing bacteria in marine Arctic sediments. Appl Environ Microbiol 66:3592-3602

Revsbech NP (1989) An oxygen microsensor with a guard cathode. Limnol Oceanogr 34:474-478

Rochelle P, Cragg B, Fry J, Parkes R, Weightman A (1994) Effect of sample handling on estimation of bacterial diversity in marine sediments by $16 \mathrm{~S}$ rRNA gene sequence analysis. FEMS Microbiol Ecol 15:215-226

Sahm K, Berninger UG (1998) Abundance, vertical distribution, and community structure of benthic prokaryotes from permanently cold marine sediments (Svalbard, Arctic Ocean). Mar Ecol Prog Ser 165:71-80

Sahm K, MacGregor BJ, Jørgensen BB, Stahl DA (1999) Sulphate reduction and vertical distribution of sulphatereducing bacteria quantified by rRNA slot-blot hybridization in a coastal marine sediment. Environ Microbiol 1: $65-74$

Sass H, Wieringa E, Cypionka H, Babenzien HD, Overmann J (1998) High genetic and physiological diversity of sulfatereducing bacteria isolated from an oligotrophic lake sediment. Arch Microbiol 170:243-251

Schubert CJ, Ferdelman T, Strotmann B (2000) Organic matter composition and sulfate reduction rates in sediments off Chile. Org Geochem 31:351-361

Sievert S, Brinkhoff T, Muyzer G, Ziebis W, Kuever J (1999) Spatial heterogeneity of bacterial populations along an environmental gradient at a shallow submarine hydrothermal vent near Milos Island (Greece). Appl Environ Microbiol 65:3834-3842

Snaidr J, Amann R, Huber I, Ludwig W, Schleifer KH (1997) Phylogenetic analysis and in situ identification of bacteria in activated sludge. Appl Environ Microbiol 63: $2884-2896$

Sørensen J, Christensen D, Jørgensen BB (1981) Volatile fatty acids and hydrogen as substrates for sulfate-reducing bacteria in anaerobic marine sediment. Appl Environ Microbiol 42:5-11

Taylor J, Parkes J (1983) The cellular fatty acids of the sulphate-reducing bacteria, Desulfobacter sp., Desulfobulbus sp. and Desulfovibrio desulfuricans. J Gen Microbiol 129:3303-3309

Thamdrup B, Fossing H, Jørgensen BB (1994) Manganese, iron, and sulfur cycling in a coastal marine sediment, Aarhus Bay, Denmark. Geochim Cosmochim Acta 58: 5115-5129

Trudinger P (1992) Bacterial sulfate reduction: current status and possible origin. In: Schidlowski M, Golubic S, Kimberley M, McKirdy D, Trudinger P (eds) Early organic evolution. Springer, Berlin, p 367-377

Vainshtein M, Hippe H, Kroppenstedt RM (1992) Cellular fatty acid composition of Desulfovibrio species and its use in classification of sulfate-reducing bacteria. Syst Appl Microbiol 15:554-566

Volkman JK, Rohjan D, Rullkötter J, Scholz-Böttcher BM, Liebezeit G (2000) Sources and diagenesis of organic matter in tidal flats sediments from the German Wadden Sea. Cont Shelf Res 20:1139-1158

Vosjan J (1974) Sulphate in water and sediment of the Dutch Wadden Sea. Neth J Sea Res 8:208-213

Wallner G, Amann R, Beisker W (1993) Optimizing fluorescent in situ-hybridization with rRNA-targeted oligonucleotide probes for flow cytometric identification of microorganisms. Cytometry 14:136-143

Widdel F (1988) Microbiology and ecology of sulfate- and sulfur-reducing bacteria. In: Zehnder AJB (ed) Biology of 
anaerobic microorganisms. John Wiley \& Sons, New York p 469-585

Widdel F, Bak F (1992) Gram-negative mesophilic sulfatereducing bacteria. In: Balows A, Trüper HG, Dworkin $\mathrm{M}$, Harder W, Schleifer KH (eds) The prokaryotes, 2nd edn Vol 3. Springer-Verlag, New York, p 3352-3378

Wieringa E, Overmann J, Cypionka H (2000) Detection of

Editorial responsibility: Gary King,

Walpole, Maine, USA abundant sulphate-reducing bacteria in marine oxic sediment layers by a combined cultivation and molecular approach. Environ Microbiol 2:417-427

Wollast R (1991) The coastal organic carbon cycle: fluxes, sources, and sinks. In: Mantoura RFC, Martin JM, Wollast $\mathrm{R}$ (eds) Ocean margin processes in global change. John Wiley \& Sons, New York, p 365-381

Submitted: January 17, 2002; Accepted: May 1, 2002 Proofs received from author(s): September 19, 2002 